\title{
浸水実績・降雨記録を用いた機械学習に基づく 簡易浸水予測システム \\ SIMPLE INUNDATION EVALUATION SYSTEM BASED ON MACHINE LEARNING USING INUNDATION AND RAINFALL RECORDS IN THE PAST
}

\author{
高橋俊彦 1 ・平山康典 2 -天野玲子 3 ・武田誠 4 ・松尾直規 5 \\ Toshihiko TAKAHASHI, Yasunori HIRAYAMA, Reiko AMANO, \\ Makoto TAKEDA and Naoki MATSUO
1正会員 理修 鹿島建設株式会社 技術研究所（干182-0036 東京都調布市飛田給二丁目19-1）
2鹿島建設株式会社Ｉ Tソリューション部（†107-8348 東京都港区赤坂六丁目5-11）
3 正会員 工博 鹿島建設株式会社 土木管理本部（干107-8348 東京都港区赤坂六丁目5-11） \\ 4正会員 博士(工) 中部大学准教授 工学部都市建設工学科（一487-8501 愛知県春日井市松本町1200） \\ 5フェロー 工博 中部大学教授 工学部都市建設工学科（†487-8501 愛知県春日井市松本町1200）
}

\begin{abstract}
A new simple inundation evaluation method based on the support vector machine, which is one of machine learning methods, using inundation and rainfall records in the past as training data, is proposed. Formulation on the application of the support vector machine to the inundation evaluation is fully described. The system, in which the inundation evaluation method as well as visualizing tools is implemented, has been developed. By comparison of the inundation hazard predicted by this system and the actual inundation that occurred recently, the effectiveness and applicability of this system are discussed.
\end{abstract}

Key Words : Machine learning, support vector machine, inundation evaluation

\section{1. はじめに}

治水対策における有力な検討ツールとして，洪水汇濫 解析手法が広く提案されてきており，その有効性，実用 性が検証されている1)，2，3)，4)．特に都市部を対象とする 場合, 高層ビル, 道路等の都市構造物や下水道システム までも考慮した高度な汇濫解析が実施されるようになっ てきている. しかし, 地表面, 下水道, 河川等を連成さ せた高度な非定常計算を実施するためには，通常多大な 労力, 計算時間を要する.

一方, 土木工事現場での安全管理, 建築案件の計画立 案等においては，いきなり高度な洪水汇濫解析を実施す るのではなく，まずは簡易的な検討で豪雨時の浸水可能 性を把握することが一般的に行われている. 具体的には, 自治体から公表されている洪水ハザードマップ，防災 マップ等が参照されている.

本論文では，以上の背景を踏まえ，全く別のアプロー チとして，過去に発生した豪雨時の浸水実績・降雨記録 のデータを用いて，それらを機械学習することによって
将来想定される豪雨時での浸水予測を行うことを試みる。 機械学習の土木分野への適用として, 近年, 斜面の諸元 データと災害履歴を学習することで災害危険度を評価す $る^{5)}$, 公共施設の目視点検結果を学習することで総合的

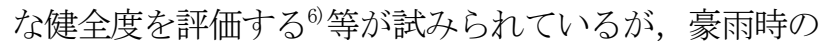
浸水予測への適用はまだ行われていない。ここでは，そ の第1ステップとして，浸水実績・降雨記録のデータが 公開されている東京23区を対象に，機械学習寸ることで 簡易的な浸水予測ができるシステムを構築したので，そ の内容を詳述するとともにその適用性について検討寸る.

\section{2. 機械学習手法の概要}

機械学習とは, パターン認識, ゲーム戦略, プラント 制御等の様々な種類の学習課題を対象として, 学習する システムのアーキテクチャーや学習アルゴリズムを研究 する分野の総称である．機械学習手法としては，ニュー ラルネットワーク (以下NN)が古くから広く知られており， 1980年代には, 多層パーセプトロンとその学習アルゴリ 
ズムのバックプロパゲーションの導入によって多くの分 野へ適用されたが, 実用面では過剩学習, 収束の遅さ等 の問題も指摘されている. 一方, サポートベクターマシ ン(以下SVM $)^{71}$ は，2值識別問題を解くために考えられた 学習アルゴリズムであるが, 各種の問題に適用されてそ の優秀性が確認されている, 理論的なサポートがある, 実際問題への適用が容易である等の理由から注目を集め ている. SVMは，非線形の識別関数へも拡張可能である が，ここでは線形識別関数を求める線形SVMを適用寸る. 線形SVM は, $N$ 次元ベクトル $x$ に対する 2 值識別問題 の学習を対象とする. 入力データの集合 $x^{1}, \cdots, x^{\ell}$ ( $N$ 次元ベクトル) に対して，それぞれ出力ラベル1ある いは-1が割り当てられている学習用データの集合が与え られているとする. このとき, 入力データ $x$ の各要素 $x_{i}(i=1, \ldots . . ., N)$ を重み $w_{i}$ で足し合わせ，その符号を 出力する関数を線形識別関数と呼ぶ. 線形SVMは, $\ell$ 個 の学習用データの集合に対して, 出力ラベル1と-1のも のを分離するような線形識別関数を求める問題である.

\section{3. 線形SVMIよよる浸水予測の定式化}

まず，過去に発生した豪雨時の浸水実績図をメッシュ 分割し, 各メッシュに対して, 何らかの基準に基づいて 豪雨時に浸水したか，しなかったかを判定する，そうす ると,メッシュ毎に，過去に発生したすべての豪雨時で の浸水有無がわかるデータベースが生成される．ここで は，このデータベースを基に学習用データの集合を設定 し, 線形識別関数を求める線形SVMを考える.

学習用データの集合を設定するに当たって, 入力デー タとしては, 選定された雨量観測所における雨量代表值 からなるベクトル, 出力ラベルとしては, それぞれ浸水 有が1，浸水無が-1とする.

各メッシュに対して，学習用データの集合は以下で表 現される.

$$
\begin{gathered}
S=\left\{\left(x_{1}, y_{1}\right), \ldots . .,\left(x_{\ell}, y_{\ell}\right)\right\}, \\
x_{i} \in R^{N}, \quad y_{i} \in\{1,-1\}
\end{gathered}
$$

ここで,

$S$ : 学習用データの集合,

$x_{i}:$ 雨量観測所における雨量代表值,

$y_{i}:$ 浸水有の場合 $=1$, 浸水無の場合 $=-1$,

$\ell$ : 学習用データの個数

$N$ : 選定された雨量観測所の数

である.

$x_{i}(i=1, \ldots . ., \ell)$ を $R^{N}$ の超平面によって, $y_{i}=1$ と

$y_{i}=-1$ のグループに線形分離することを考える(図-1 参照)，候補となる超平面は，図-1の2本の黒線で挟まれ る範囲に属し，一般には次式で表される.

$$
w^{T} x+b=0
$$

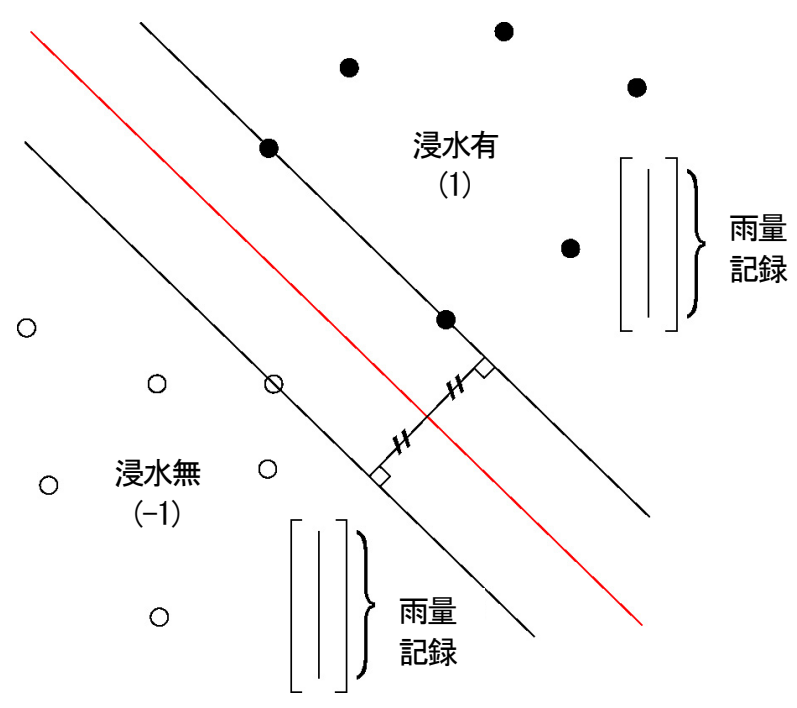

図-1＼cjkstart超平面による学習用データの分離

ここで,

$w=\left(w_{1}, w_{2}, \ldots . ., w_{N}\right) \in R^{N}:$ 重み,

$b \in R$ : 定数

である.

また，線形識別関数を以下で定義しておく.

$$
f(x)=\operatorname{sgn}\left(w^{T} x+b\right)
$$

ここで,

$\operatorname{sgn}(z): z$ が正または0ならば1, 負ならば-1

とする.

超平面に対するサンプル学習用データ $\left(x_{i}, y_{i}\right)$ のマー ジン $d_{i}$ は, 次式で計算される.

$$
d_{i}=y_{i}\left(w^{T} x_{i}+b\right) /\|w\|, \quad i=1, \ldots . ., \ell
$$

ここで,

$$
\|w\|=\sqrt{\sum_{j=1}^{N} w_{j}^{2}}
$$

である. $d_{i}$ が正ならば $\left(x_{i}, y_{i}\right)$ が正しく識別されてい ることになり, その場合, $d_{i}$ の值は点 $x_{i}$ から超平面ま での距離となっている.

学習用データの集合が線形分離可能であるとすると,

$$
y_{i}\left(w^{T} x_{i}+b\right)>0, \quad i=1, \ldots ., \ell
$$

となるような超平面が存在することになるので, 以下の ように超平面を正規化することができる.

$$
\min _{1 \leq i \leq \ell} y_{i}\left(w^{T} x_{i}+b\right)=1
$$

このとき, 超平面のマージンは $1 /\|w\|$ となる. 最適な超 平面はマージンが最大となる場合と考えられるので，以 下の最小化問題の解として特徵付けられる. これは, 図-1の赤線に対応している.

$$
\begin{aligned}
& \min _{w, b} \frac{1}{2}\|w\|^{2}, \\
& w \in R^{N}, b \in R
\end{aligned}
$$

subject to $y_{i}\left(w^{T} x_{i}+b\right) \geq 1$,

$i=1, \ldots \ldots, \ell$ 
最小化問題 (8) は凸2次計画問題8)であり，直接解くこ とは可能であるが，双対問題 ${ }^{8}$ を考えた方が都合良いの でここでは以下のWolfeの双対問題8)を考える.

$$
\begin{aligned}
& \max L(w, b, \alpha), \\
& w \in R^{N}, b \in R, \alpha \in R^{\ell} \\
& \text { subject to } \nabla_{w} L(w, b, \alpha)=0 \text {, } \\
& \nabla_{b} L(w, b, \alpha)=0, \quad \alpha \geq 0 \\
& L(w, b, \alpha) \\
& =\frac{1}{2}\|w\|^{2}-\sum_{i=1}^{\ell} \alpha_{i}\left(y_{i}\left(w^{T} x_{i}+b\right)-1\right)
\end{aligned}
$$$$
\text { ここで, }
$$

である。

$\alpha$ : 双対変数,

凸計画問題に対する最適性の必要十分条件である Karush-Kuhn-Tucker条件 ${ }^{8)}$ を考慮すると，双対問題(9) は 以下に帰着される.

$$
\begin{aligned}
& \max _{\alpha}-\frac{1}{2} \sum_{i=1}^{\ell} \sum_{j=1}^{\ell} \alpha_{i} \alpha_{j} y_{i} y_{j} x_{i}{ }^{T} x_{j}+\sum_{i=1}^{\ell} \alpha_{i}, \\
& \alpha \in R^{\ell} \\
& \text { subject to } \sum_{i=1}^{\ell} \alpha_{i} y_{i}=0, \quad \alpha_{i} \geq 0, \\
& i=1, \ldots ., \ell
\end{aligned}
$$

双対問題 $(11)$ は非口2次計画問題8)であり，数值計算的 には不安定となる可能性が高い. そこで, 線形分離でき ない場合も考慮してソフトマージンを導入するとともに, 数值計算上安定となるような定式化を考える.まず，最 小化問題 $(8)$ の制約条件にスラック変数を導入して、以 下のように変換する.

$$
\begin{aligned}
& y_{i}\left(w^{T} x_{i}+b\right) \geq 1-\xi_{i}, \quad \xi_{i} \geq 0, \\
& i=1, \ldots ., \ell
\end{aligned}
$$

スラック変数の值は極力小さくすべきであるので，目的 関数にペナルティー項を付加することになるが，最終的 に解くべき問題が凸2次計画問題となるように，ここで は以下の問題を考える.

$$
\begin{aligned}
& \min _{w, b, \xi} \frac{1}{2}\|w\|^{2}+\frac{C}{2} \sum_{i=1}^{\ell} \xi_{i}^{2}, \\
& w \in R^{N}, \quad b \in R, \quad \xi \in R^{\ell} \\
& \text { subject to } y_{i}\left(w^{T} x_{i}+b\right) \geq 1-\xi_{i}, \\
& i=1, \ldots ., \ell
\end{aligned}
$$

上述と同様に，Karush-Kuhn-Tucker条件を用いて整理 すると，以下の双対問題が得られる.

$\max _{\alpha}-\frac{1}{2} \sum_{i=1}^{\ell} \sum_{j=1}^{\ell} \alpha_{i} \alpha_{j} y_{i} y_{j}\left(x_{i}{ }^{T} x_{j}+\frac{1}{C} \delta_{i j}\right)+\sum_{i=1}^{\ell} \alpha_{i}$, $\alpha \in R^{\ell}$

subject to $\sum_{i=1}^{\ell} \alpha_{i} y_{i}=0, \quad \alpha_{i} \geq 0$,
ここで, $\delta_{i j}$ はKroneckerのデルタ記号で, $i=j$ の時1, それ以外の時0である。

双対問題 (14) は非口2次計画問題ではなく，凸2次計画 問題であるので, 数值計算上安定に解くことができる. 凸2次計画問題を解くプログラムは，これまでに数多く 開発されてきており，十分な実績を持つとともに一般に 公開されているものも少なくない. いずれにしても, 双 対問題 (14) を精度良く解いて最適解 $\alpha$ * が得られると, それから元の最小化問題 (13)の最適解 $w^{*}, b^{*}, \xi^{*}$ が求 まる. 線形識別関数 $(3)$ に $w^{*}, b^{*}$ を代入した

$$
f(x)=\operatorname{sgn}\left(\left(w^{*}\right)^{T} x+b^{*}\right)
$$

を用いると, 想定される雨量観測所における雨量代表值 (任意の $x)$ に対して, 即時に浸水有無 $(f(x)=1$ あるい は $f(x)=-1)$ を判定することができる.

\section{4. 簡易浸水予測システム}

以上の定式化を組み込んで，想定豪雨時の浸水予測を 簡易的にできる簡易浸水予測システムをパソコン上で開 発した. なお，双対問題(14)に対しては，凸2次計画問 題に対する最も優れた解法の一つである双対法"9) を適用 している. 本システムの構成は，図-2に示す通りである。 最初に，過去に発生した豪雨時の浸水実績・降雨記録 に基づいて，それぞれマップ情報，選定された雨量観測 所における雨量代表值でデータベースを構築する(図-2 緑色部分)。ここでは，浸水有無を判定する上で累積雨 量, 10 分最大雨量等に比して最も影響度が大きいこと, 各雨量観測所での記録が揃っていること等の理由から， 雨量代表值として時間最大雨量を用いた。

次に，対象範囲をメッシュ分割し，メッシュ毎に入力 データとして選定された雨量観測所の時間最大雨量, 出 カラベルとして浸水有無 (1あるいは-1)の学習用データ の集合を生成する(図-2(1)部分). 学習用データの集合を 用いて，メッシュ毎に線形SVMを行うことによって，線 形識別関数 (15) が求められ(図-2(2)部分), 選定された雨 量観測所の想定時間最大雨量に対して，当該メッシュの 浸水有無が判定できる(図-2(3)部分).

以上のことから，過去に発生した豪雨時の浸水実績・ 降雨記録が整備されている場合, ユーザーは興味のある 対象範囲およびそこでの解像度 (メッシュサイズ) と想定 時間最大雨量の指定(図-2黄色部分)を行うだけで浸水有 無を予測できることがわかる.

なお，線形SVMで求められる線形識別関数の信頼性は， 一般的に入力ベクトルの次元，学習用データの個数に依 存する. 前者に対して後者が数十倍から数百倍程度ある と, 安定した学習ができることが経験的に知られている が，実際問題への適用においては，線形SVMで求められ た線形識別関数で学習用データがどのくらい再現できる かでその信頼性を評価するのが現実的な方法であろう。 


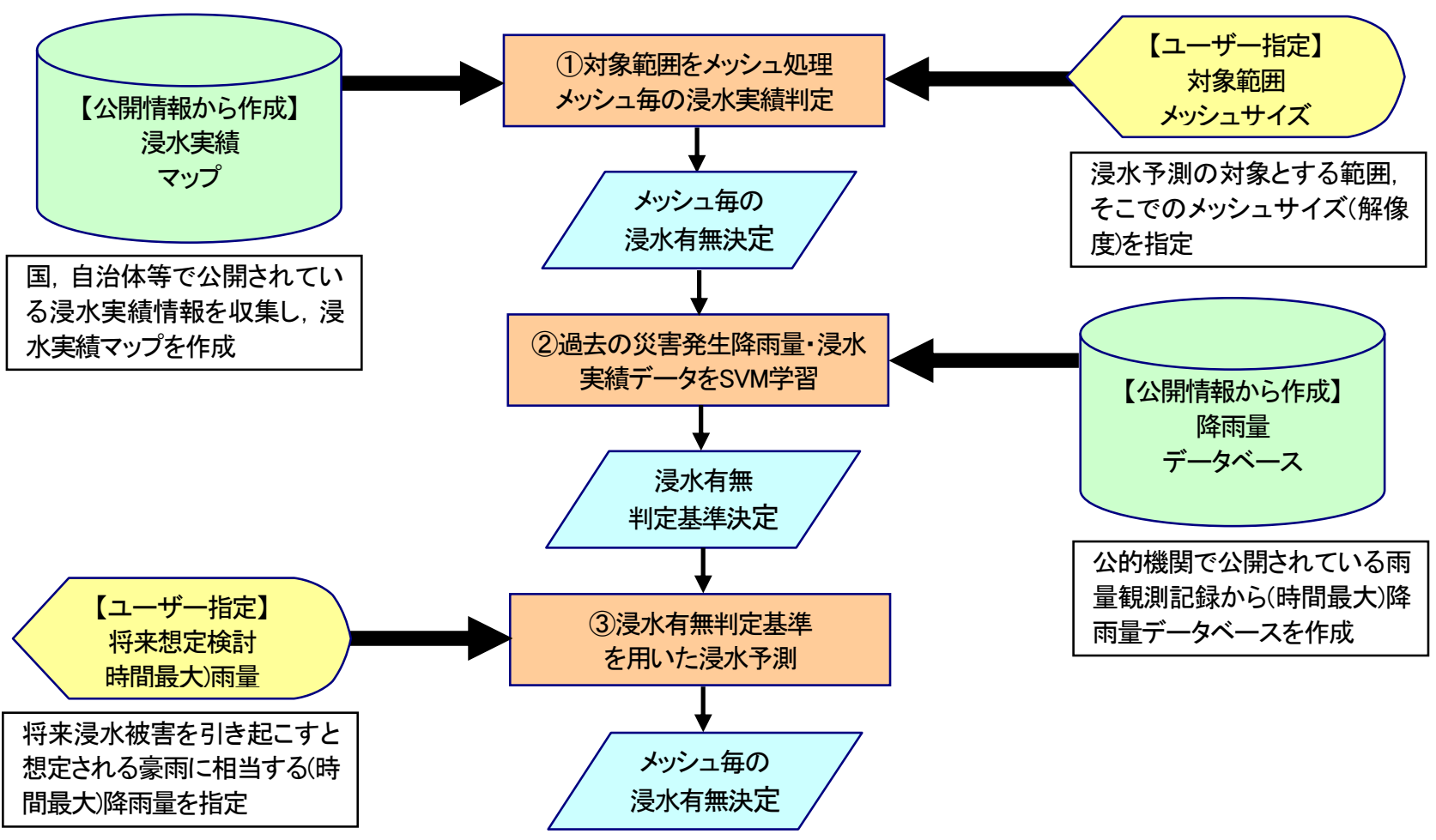

図-2 システム構成

\section{5. 東京23区への適用}

過去に発生した豪雨時の浸水実績・降雨記録の詳細な データが比較的長期間にわたって公開されている東京 23 区を対象として，簡易浸水予測システムを構築した. 1974(昭和49)～2007 (平成19)年の34年間にわたって, 詳 細な水害記録が公開10)されているが，この間雨量観測所 の位置，組み合わせ等が更新されている。ここでは，そ れらが安定してきた1995 (平成7) 2007 (平成19) 年を対 象に31の雨量観測所を選定した. なお，この対象期間中， 浸水被害が発生するような豪雨は82回記録されていたの で, 学習用データの個数は82である.

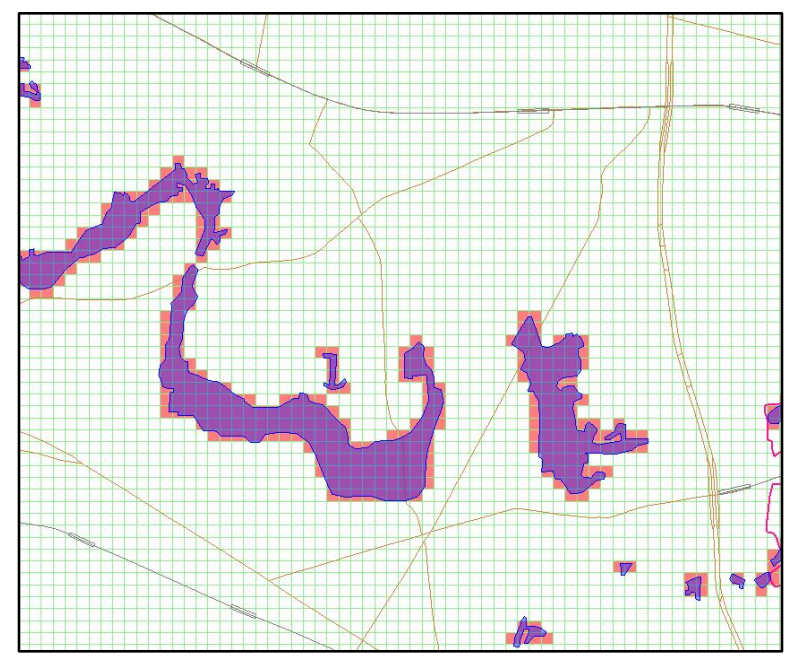

図-3 浸水実績のメッシュ処理(2005/09/04豪雨時)

\section{(1) 線形SVMの精度検証}

図-3は，2005年9月4日に発生した通称杉並豪雨を対象 にして，浸水実績マップをメッシュ処理した一例を示し ている. 青色が元の浸水実績マップで, 桃色がメッシュ 処理した結果である.ここでは，メッシュサイズは $50 \mathrm{~m}$ で，各メッシュにおいて浸水実績範囲が10\%以上含まれ ている場合，そのメッシュは浸水有と判定している.

図-4は，線形SVMによって求められた線形識別関数に 杉並豪雨を代入して得られた結果である。杉並豪雨時も 学習用データの一つだが，再現率は $100 \%$ である。こは メッシュサイズ, メッシュ浸水有無判定の設定值に依ら ず達成されており, 過剩学習, 収束の遅さ等の問題があ るNNに比して高精度かつ安定した学習が実現されている。

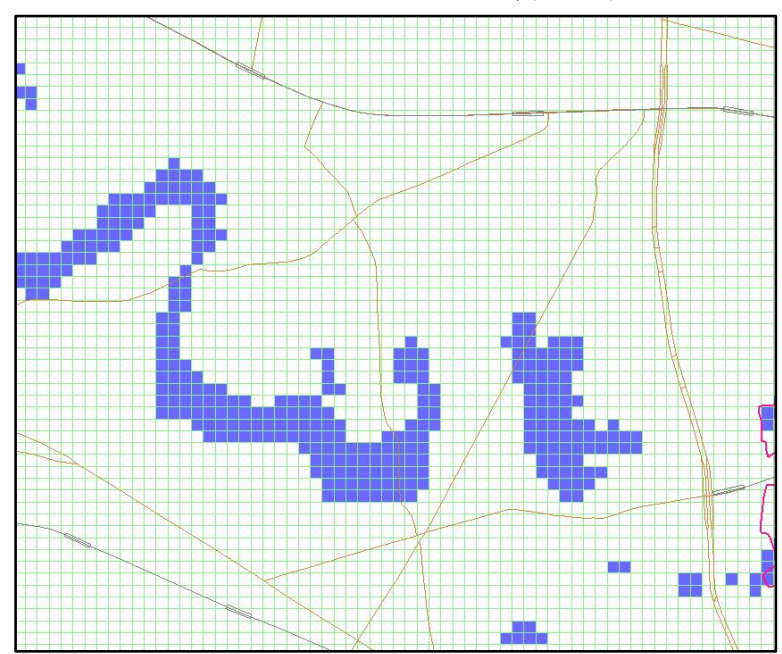

図-4＼cjkstart線形SVMによる再現(2005/09/04豪雨時) 


\section{（2）線形SVMIによる浸水予測}

簡易浸水予測システムにおける線形SVMの適用性を検 討するために，まず公開されている洪水ハザードマップ との比較を試みる。ここでは，図-5に示すように，中野 区洪水ハザードマップ ${ }^{\circ 11}$ の野方周辺に着目する. 黄色, 緑色，水色，青色は，それぞれ浸水深が $0.2 \sim 0.5 \mathrm{~m} ， 0.5$ 〜1.0m，1.0〜2.0m，2.0〜5.0mであることを示している. 中野区洪水ハザードマップでは，対象降雨は2000 (平成 12)年 9 月に発生した東海豪雨(総雨量 $589 \mathrm{~mm}$, 時間最大雨 量 $114 \mathrm{~mm})$ となっている. そこで，本システムでは，想定 豪雨として，選定された31のすべての雨量観測所で時間 最大雨量 $114 \mathrm{~mm}$ を指定した。 また，メッシュサイズは $50 \mathrm{~m}$, メッシュ浸水有無判定基準は10\%以上とした．線形SVMに よる浸水予測結果は，図-6に示寸通りである.

図-5と図-6を比較すると，浸水範囲の傾向は概ね一致 していることがわかる．洪水ハザードマップの黄色，緑 色の一部については，本システムで予測できていないと ころも見られるが，これらは1995(平成7)～2007 (平成 19)年の対象期間中浸水した実績が全くなかったため, 学習できなかったからである。

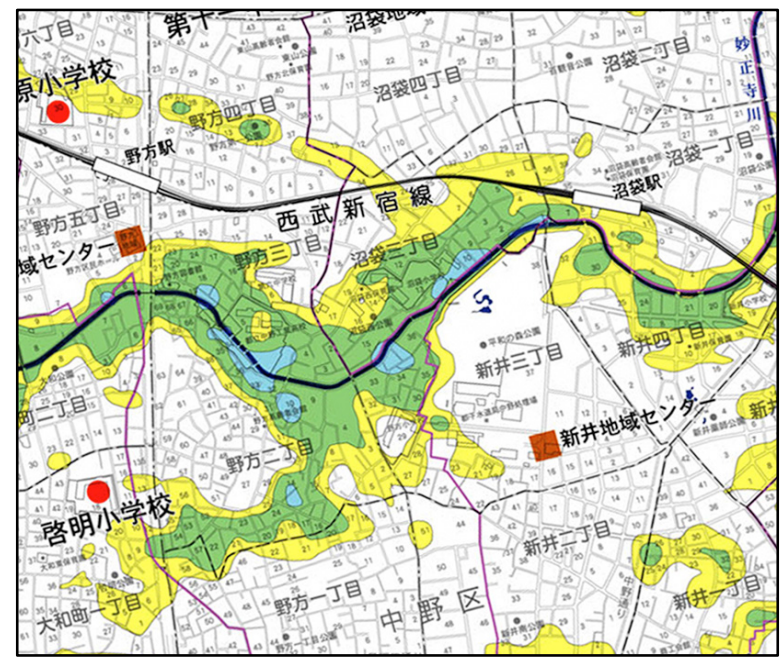

図-5４野区洪水ハザードマップ(野方周辺)

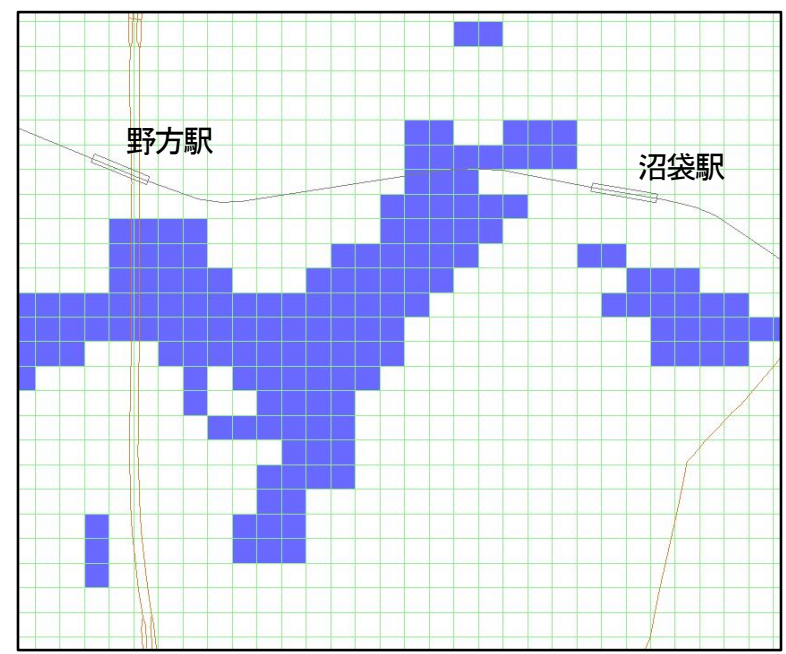

図-6 線形SVMIよる浸水予測 (野方周辺)
2010年7月5日，東京都西・北部，埼玉県西部等で局所 的な豪雨が発生し，北区，練馬区等で浸水被害が発生し た．特に北区堀船では，近くの石神井川が汇濫したため, 道路が冠水し，多大な被害が引き起こされた。この浸水 被害状況に関して，北区周辺を対象として，本システム を適用してみた。

図-7，図-8は，それぞれ1974(昭和49)～2007 (平成19) 年, 1995 (平成7) 2007 (平成19) 年に発生した豪雨時の 浸水実績困に基づいて作成した浸水範囲を示している. 色が濃い部分は，それだけ浸水発生頻度が多かったこと を意味している. 図-7と図-8を比較すると，後者は浸水 範囲が飛躍的に減少していることがわかる。これは， 1974(昭和49)～1994(平成7)年の間に実施された洪水対 策施設の建設，整備等の効果と考えられる.

図-8に示す通り，1995 (平成7)～2007 (平成19)年にお いて, 北区堀船周辺が浸水したのは1回だけで, 2003 (平成15)年10月13日の豪雨時に発生したものである. 北区全域で見ると, 浸水実績は7回記録されているが, 2003 (平成15)年10月13日の豪雨時以外の浸水範囲は僅か であった。

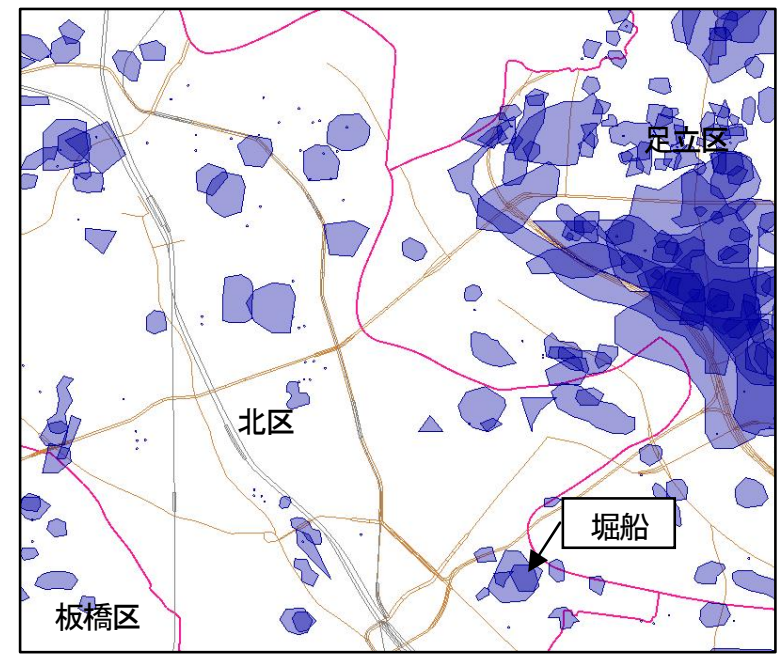

図-7 北区堀船周辺浸水実績(1974 (昭和49) 年以降)

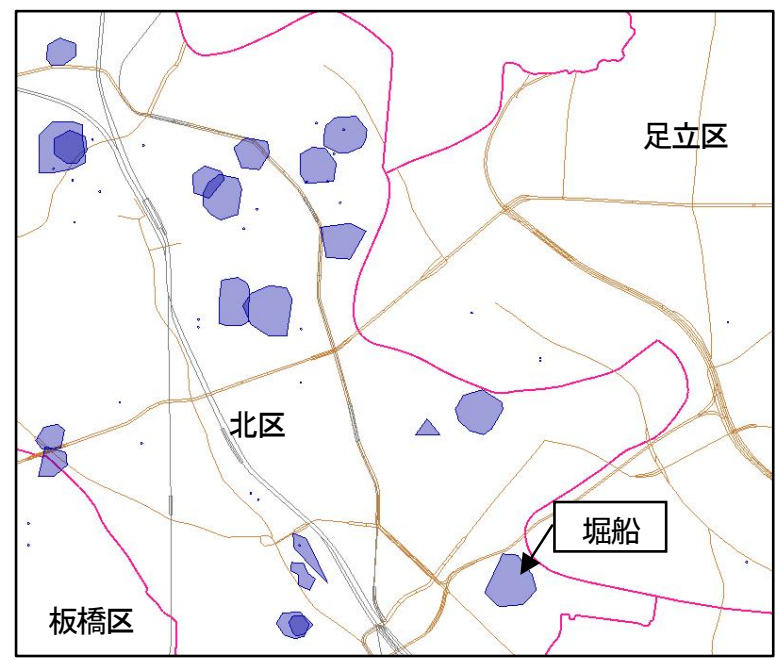

図-8 北区堀船周辺浸水実績(1995(平成7) 年以降) 


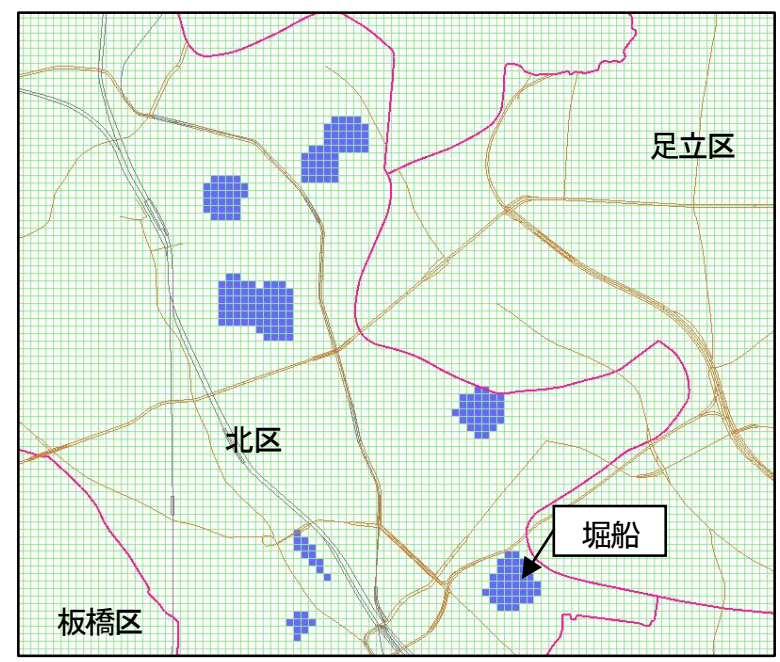

図-9 線形SVMIによる浸水予測(北区堀船周辺)

図-9は，1995 (平成7)～2007 (平成19) 年に発生した豪 雨時の浸水実績・降雨記録を学習用データとして, 線形 SVMを行って浸水範囲を予測した結果である. メッシュ サイズ，メッシュ浸水有無判定基淮は前述と同様それぞ れ50m，10\%以上である. 2010年7月5日に発生した局所的 な豪雨に相当する時間最大雨量としては，気象庁の記録 を参考に，北区周辺の雨量観測所(志茂橋，西新井，荒 川)で100m，それ以外では $50 \mathrm{~mm}$ と指定した。

図-9より，堀船周辺は浸水有の予測となっており，実 際に浸水被害が大きかった範囲が含まれている。「床 上・床下浸水全567世帯のうち, 堀船周辺が461世帯でそ れ以外はごく少数で広く分布」という北区防災課の記録 から，堀船周辺以外はあまり的中していないが，学習用 データ数82のうち, 顕著な浸水実績は1個のみで, その 影響が強いことを考慮すると，妥当な結果と考えられる．

\section{6. おわりに}

水理学的な洪水汇濫解析とは全く別のアプローチとし て，過去に発生した浸水実績・降雨記録データの機械学 習に基づいた，将来想定豪雨に対する概略の浸水予測手 法を提案するとともに，東京23区一適用することによっ て，その妥当性を確認し，適用性を検討した．本手法は， 様々な降雨状況下の浸水予測を短時間で実施できるので, 実用面において非常に有利である，得られた知見および 今後の課題は, 以下の通りである.

1）本システムによって, 想定降雨時の浸水有無の予測 は概ね可能であることが判明した．ただし，顕著な 浸水実績の学習用データ数が少ない場合, 機械学習 結果がそれらの影響を強く受け易いことも考察され た．さらに，浸水実績が全くない場合は，学習不可 能のため, いかなる降雨時においても浸水するとい う判定は下せない. 異常な豪雨時に全域が浸水する という人工的なデータを学習用データに含めるよう
な方法が考えられるが，今後の課題である.

2） 洪水対策施設の建設, 整備等に伴って, 浸水範囲の 傾向が変わってくる可能性がある. 従って, 直近の 浸水実績・降雨記録のデータが公開された場合は, 着実にデータベースを更新すると同時に, 機械学習 する場合の学習用データ (対象期間, 対象豪雨等) は, 適切に指定する必要がある.

3）公開されている浸水実績・降雨記録のデータを学習 用データとするのが基本であるが，対象とする範囲 において既に洪水汇濫解析モデルが整備されている のであれば，数十程度の想定豪雨に対して計算を 行って，それらの結果を学習用データと見なして本 システムを構築することも可能である.

謝辞 : SVMに関して，(独) 産業技術総合研究所知能シス テム研究部門インタラクションモデリング研究グループ の麻生英樹主任研究員より貴重なアドバイスをいただい た.ここに記して謝意を表する.

\section{参考文献}

1) 戸田圭一, 井上和也, 村瀬賢, 市川温, 横尾英男 : 豪雨によ る京都市域の汇濫解析，水工学論文集，第44巻，pp.479-484， 2000.

2) 関根正人, 河上展久 : 都市における内水汇濫と地下街浸水の 被害予測に関わる数值解析, 水工学論文集, 第 47 巻, pp.889-894, 2003.

3) 川池健司, 井上和也, 戸田圭一, 野口正人 : 寝屋川流域を対 象とした汇濫解析モデルの高度化, 水工学論文集, 第 47 巻, pp.919-924, 2003.

4) 武田誠, 松尾直規, 山中威士, 森田豊 : 総合的な汇濫解析シ ステムの構築に関する研究, 水工学論文集, 第 49 巻, pp.613-618, 2005.

5) 大石博之, 小林央宜, 尹禮分, 田中浩一, 中山弘隆, 古川浩 平 : サポートベクターマシンによる対策工効果を考慮した斜 面災害危険度の設定，土木学会論文集F，Vol.63，No.1， pp.107-118, 2007.

6) 杉本博之，一間恵伍，阿部淳一，古川浩平 : SVMによる社 会基般施設の健全度の総合的評価とそれによる順位付けに関 寸る研究，土木学会論文集A，Vol.65，No.3，pp.658-669, 2009.

7) Vapnik, V. N.: Statistical Learning Theory, John Wiley \& Sons: New York, 1998.

8) 例えば, 今野浩, 山下浩: 非線形計画法, 日科技連, 1978.

9) Goldfarb, D and Idnani, A: A numerically stable dual method for solving strictly convex quadratic programs, Mathematical Programming, Vol.27, pp.1-33, 1983.

10) http://www.kensetsu.metro.tokyo.jp/suigai_kiroku/kako.htm

11) http://www.city.tokyo-nakano.lg.jp/dept/158000/d002981.html

(2010. 9. 30受付) 